\title{
Where IS THE HoOsier Hospitality? THE EVER-EVOLVING CHILD-PARENT RELATIONSHIP AND INDIANA'S NEED FOR GENDER-NEUTRALITY
}

\author{
BRADLEY LOHSL*
}

\section{INTRODUCTION}

"The Constitution promises liberty to all within its reach, a liberty that includes certain specific rights that allow persons, within a lawful realm, to define and express their identity." To many in the Lesbian, Gay, Bisexual, and Transgender (LGBT) community, this impactful sentence in the opening line of Obergefell $v$. Hodges provided the prospect that the decision could extend beyond the realm of gay marriage and help the LGBT community as a whole in their fight for equality. ${ }^{2}$

Prior to the U.S. Supreme court handing down this seminal same-sex rights decision, the federal government denied same-sex couples many benefits linked to marriage provided to opposite-sex couples. ${ }^{3}$ In its Obergefell holding, the Court specifically denied states the ability to "exclude same-sex couples from civil marriage on the same terms and conditions as opposite-sex couples." ${ }^{\prime 4}$ In doing so, for the first time, the Court afforded same-sex couples the ability to be listed on their children's birth and death certificates by expressly identifying both birth certificates and death certificates in listing the terms and conditions. ${ }^{5}$ As a result, many courts have been moving towards granting same-sex couples more family law rights and obligations.

But same-sex couples continue to face many family law issues that must be addressed. This Note discusses the specific issue of married female same-sex couples being denied their right of having both spouses listed on their child's birth certificate. Additionally, this Note examines another class of people: Those in the transgendered community who are fighting for equality. This Note further advocates for the Indiana General Assembly and Indiana State Department of Health to amend the existing language used in their respective statutes or

* J.D. Candidate, 2019, Indiana University Robert H. McKinney School of Law; B.S. 2013, Indiana University - Bloomington, Indiana. I would like to thank my faculty advisor, Professor Margaret Ryznar, for her support and insight during the Note development process. I would also like to thank my beautiful wife for her constant love and support of my academic goals.

1. Obergefell v. Hodges, 135 S. Ct. 2584, 2601 (2015).

2. David B. Cruz, Transgender Rights After Obergefell, 84 UMKC L. REV. 693, 696 (2016).

3. Obergefell, 135 S. Ct. at 2601.

4. Id. at 2605.

5. See id. at 2601 (Justice Kennedy's majority opinion provided that taxation, inheritance and property rights, rules of intestate succession, spousal privilege in the law of evidence, hospital access, medical decision-making authority, adoption rights, the rights and benefits of survivors, birth and death certificates, professional ethics rules, campaign finance restrictions, workers' compensation benefits, health insurance, and child custody, support, and visitation rules are terms and conditions of marital status.). 
documents that confer parental rights to be more inclusive and gender-neutral.

In many states, a child's birth certificate cannot legally list the non-birthing mother in a same-sex couple as a parent. ${ }^{6}$ In Indiana, a woman's male spouse is presumed to be the father of her child, unless proven otherwise. ${ }^{7}$ This parentage presumption permits the "birth mother" to have her husband's information listed on her child's birth certificate, which provides him rights that others do not have over the child. However, a female spouse of a birth mother is not afforded the same presumption. ${ }^{8}$ Instead, state law forbids her from being listed on the birth certificate and gaining any rights to the child. ${ }^{9}$ If the female spouse desires legal rights over the child her wife gave birth to, she must go through a lengthy and expensive adoption process. ${ }^{10}$

When a parent is listed on their child's birth certificate, that parent acquires something much more significant than a symbolic relationship that is kept on file at a local registrar office. This is because being listed on a birth certificate provides both the parent and the child significant rights they would not otherwise have. For instance, birth certificates are often used in important events like making medical decisions or enrolling a child in school. ${ }^{11}$ Additionally, a birth certificate may be used for survivor benefits if one spouse passes away, for inheritance purposes, and to establish a parent-child relationship in the event of a divorce. $^{12}$

This Note argues that the Indiana Parenthood Statutes, ${ }^{13}$ Indiana Code sections 31-9-2-15, 31-9-2-16, and 31-14-7-1, and the Indiana Live Birth Worksheet $^{14}$ discriminate against lawfully married same-sex couples and transgendered Hoosiers. The statutes at issue provide the language that defines when a child is born "in wedlock" or "out of wedlock" and also the language that affords a male spouse a presumption of parentage, which is not provided to a female spouse. Further, this Note argues that current Indiana law unconstitutionally violates both the Equal Protection and Due Process Clauses of the Fourteenth Amendment and proposes gender-neutral language that must be adopted to make Indiana's Parenthood Statutes compliant with the recent U.S.

6. See e.g., Henderson v. Adams, 209 F. Supp. 3d 1059, 1072 (S.D. Ind. 2016).

7. IND. CODE $§ 31-9-2-15$ (2019).

8. Henderson, 209 F. Supp. 3d at 1072.

9. Id.

10. Id.

11. Pavan v. Smith, 137 S. Ct. 2075, 2078 (2017).

12. Order at 4, Pavan v. Smith, 2015 WL 12990015 (Ark. Cir. 2015) (No. CV2015003153).

13. This note will refer to IND. CODE $\S \S 31-9-2-15,31-9-2-16$, and 31-14-7-1 as being Indiana's "Parenthood Statutes." The Parenthood Statutes are enacted by the Indiana General Assembly.

14. Ind. State Dep't of Health, Certificate of Live Birth Worksheet, Version 30 at 1-12 (2017), available at http://ai.org/isdh/files/ibrs\%20worksheet\%20v30.pdf [https://perma.cc/ M88Q-NJG3] [hereinafter IND. CERTIFICATE OF LIVE BIRTH WorksheET]. The Indiana Live Birth Worksheet is a document that collects information to create a child's birth certificate. The document is enforced by the Indiana State Department of Health. 
Supreme Court's decision in Pavan v. Smith. ${ }^{15}$ Although neither Obergefell nor Pavan explicitly provide that states must recognize transgender rights, this Note explores the Transgender Rights Movement and advocates for the Indiana General Assembly and the Indiana State Department of Health to amend the language of their respective statutes and document to reflect the interests and rights of the transgender community.

Part I begins by analyzing the June 2017 U.S. Supreme Court case Pavan v. Smith $^{16}$ and provides summaries of the Plaintiffs' challenge against the State of Arkansas and the Court's holding. Part II looks at the current state of the law in Indiana. It first examines Henderson v. Adams, ${ }^{17}$ an Indiana case heard by the Seventh Circuit and awaiting adjudication. Part II then takes a detailed look at the Parenthood Statutes ${ }^{18}$ and recent changes to the Live Birth Worksheet. ${ }^{19}$ Finally, it concludes by considering language-previously proposed by an Indiana senator - to include same-sex couples in the Parenthood Statutes. ${ }^{20}$

Part III examines how other states - namely California, Oregon, and New York-have approached this same issue. These states have adopted language to allow same-sex couples the same rights as their opposite-sex counterparts. Additionally, at least some of the language adopted by these states provides an example of gender-neutral language. Part III demonstrates how the Indiana General Assembly and Indiana State Department of Health could benefit from looking to these states as examples in amending their respective statutes and forms.

Part IV of this Note argues that the Indiana General Assembly and the Indiana State Department of Health need to consider transgender rights in amending their respective statutes and documents as to avoid future litigation. It will first provide a short background on what the term "transgender" means. It will then examine how the Transgender Rights Movement is comparable to other civil rights movements in U.S. history. It will also analyze the precedent set by the Indiana Court of Appeals regarding what is required for a person to legally change their gender. Part IV concludes by detailing why including gender-neutral language ${ }^{21}$ in the Indiana Parenthood Statutes and Indiana's Live Birth Worksheet would not conflict with other statutes and would provide transgendered persons more protection in the area of family law.

Finally, Part V proposes gender-neutral language for both the Parenthood Statutes and Indiana's Live Birth Worksheet. Part V argues that Indiana Senator Mark Stoops' proposed language to the Indiana Parenthood Statutes, as well as the recent amended language on Version 30 of Indiana's Live Birth Worksheet,

15. Pavan, 137 S. Ct. at $2078-79$.

16. Id. at 2078.

17. Henderson v. Adams, 209 F. Supp. 3d 1059, 1072 (S.D. Ind. 2016).

18. IND. CODE $\S \S 31-9-2-15,31-9-2-16$, and 31-14-7-1 (2019).

19. Ind. Certificate of Live Birth Worksheet, supra note 14.

20. S. 393, 120th Gen. Assemb., Reg. Sess. (Ind. 2017).

21. In an effort to promote the use of gender-neutral language, this article will frequently use "they," "their," and "them" as singular, gender-neutral pronouns for transgender individuals. 
is still under-inclusive. ${ }^{22}$ In so arguing, Part V shows how the language used in each respective statute and document is not as complete enough to ensure that the State stays ahead of future LGBT lawsuits that are likely to arise in the coming years.

\section{PAVAN V. SMITH}

Pavan v. Smith, a recent decision of the U.S. Supreme Court, effectively nullified the constitutionality of the current Indiana Parenthood Statutes. In 2015, three legally married female same-sex couples in Arkansas had children. ${ }^{23}$ Each child was conceived through artificial insemination and birthed by one of the women in each couple. ${ }^{24}$ In all three couples, the "non-birth mother" filed the appropriate documents to be listed as a parent on her child's birth certificate, but was denied that right by the Arkansas Department of Health, Bureau of Vital Statistics. ${ }^{25}$ Relying on A.C.A. $\S \S 20-18-401$ and 20-18-406, the Arkansas Department of Health refused to amend the children's birth certificates to reflect the non-birth mother, absent a court order. ${ }^{26}$ The statutes provided that a "mother" shall be the woman who gave birth to the child, and if that woman was married at the time of conception or birth, her husband's name would also be listed on the child's birth certificate. ${ }^{27}$ Further, the statutes provided that a person's birth certificate may be amended only when that person has been "legitimated." 28

Essentially, A.C.A. § 20-18-401 afforded the husband of a birth mother a presumption of paternity, regardless if the child was biologically his. ${ }^{29}$ The statute did not provide that the husband had to be the biological father of the child in order to be listed on the birth certificate. ${ }^{30}$ Indeed, the husband could have met and married the mother a week before she gave birth and would still be considered the father for purposes of the birth certificate. ${ }^{31}$ Additionally, A.C.A. $\S 20-18-406$ did not recognize same-sex couples as being "in wedlock" thereby rendering their children "illegitimate." 32 However, each of the three couples had legally married prior to the birth of their children. Hence, these children did not need to become "legitimized" as they were born to married parents. ${ }^{33}$

22. Ind. Certificate of Live Birth Worksheet, supra note 14.

23. Order at 1, 4, Pavan v. Smith, 2015 WL 12990015 (Ark. Cir. 2015) (No. CV2015003153).

24. Id. at 3 .

25. Id. at $3-4$

26. Id.; see generally ARK. CODE ANN. §§ 20-18-401, -406 (2019).

27. ARK. CODE ANN. § 20-18-401.

28. Id. § 20-18-406; see Legitimate, BLACK's LAW DiCTIONARY (10th ed. 2014) (providing that the term legitimate refers to a child "born of legally married parents").

29. ARK. Code AnN. § 20-18-401.

30. Pavan v. Smith, 137 S. Ct. 2075, 2078 (2017).

31. See id.

32. ARK. CODE ANN. § 20-18-406.

33. Order at 1, Pavan v. Smith, 2015 WL 12990015 (Ark. Cir. 2015) (No. CV2015003153). 
After a disagreement among the lower courts as to the constitutionality of the statutes, the U.S. Supreme Court granted certiorari. ${ }^{34}$ The Court held that the denial of female same-sex married couples from both being listed as a parent on their child's birth certificate denied them access to the "constellation of benefits that Arkansas linked to marriage and thus was unconstitutional to the extent that the statute treated same-sex couples differently form opposite-sex couples." ${ }^{35}$ The court rejected Arkansas's argument that the statutes were intended as a recording device for biological parentage because their laws made birth certificates about more than just genetics. ${ }^{36}$ If the true intent of the statutes was to uphold the genetic integrity of parentage, then the State would not list a birthing mother's male spouse on the birth certificate without proof that he was in fact the child's biological father. ${ }^{37}$

\section{INDIANA'S CURRENT APPROACH}

Because of Pavan v. Smith, ${ }^{38}$ Indiana Code sections 31-9-2-15, ${ }^{39}$ 31-9-2-16, ${ }^{40}$ and $31-14-7-1,{ }^{41}$ are unconstitutional because they violate both the Equal Protection Clause and the Due Process Clause of the Fourteenth Amendment. ${ }^{42}$ As a result, the Seventh Circuit will likely follow the Pavan for an Indiana case pending before it. ${ }^{43}$ Additionally, although the amended language in Version 30 of Indiana's Live Birth Worksheet allows same-sex couples the ability to provide both spouses' information, the Indiana State Department of Health has omitted important language and remains vulnerable to future lawsuits. ${ }^{44}$ But regardless of Henderson's outcome, at least one Indiana state senator has recognized the inequality that these women are fighting against and has proposed inclusive language to amend the Indiana Parenthood Statutes. ${ }^{45}$

\section{A. Indiana's Current Law}

While Pavan was making its way from Arkansas to the U.S. Supreme Court, a similar case in Indiana was also making its way through the courts. Henderson v. Adams challenged the Indiana Parenthood Statutes and is still under advisement in the Seventh Circuit. ${ }^{46}$

34. Pavan, 137 S. Ct. at 2076.

35. Id. at 2078 .

36. Id.

37. Id.

38. $I d$. at 2075.

39. IND. CODE § 31-9-2-15 (2019).

40. Id. $\S 31-9-2-16$.

41. Id. § 31-14-7-1.

42. See Pavan, 137 S. Ct. at 2075.

43. Henderson v. Adams, 209 F. Supp. 3d 1059 (S.D. Ind. 2016).

44. Ind. Certificate of Live Birth Worksheet, supra note 14.

45. See S. 393, 120th Gen. Assemb., Reg. Sess. (Ind. 2017).

46. Henderson v. Adams, No. 17-1141 (7th Cir. filed Jan. 23, 2017). 
1. Henderson v. Adams. - Similar to Pavan, eight Indiana female same-sex married couples filed suit, each claiming that their respective counties unlawfully denied them their right of having both spouses listed on their child's birth certificate.$^{47}$ Each couple properly filled out Indiana's Live Birth Worksheet, ${ }^{48}$ but the respective counties refused to list the non-birthing spouse on the birth certificate, absent a court order. ${ }^{49}$

Each of the eight couples provided the court with significant reasons for needing to have both spouses listed on their child's birth certificate, and at least two of them listed health insurance as one of their primary reasons. ${ }^{50}$ In those two cases, the non-birthing spouse's job provided their child with health insurance. If the birthing spouse - the sole parent named on the birth certificate - died, the child would lose coverage because the insurance providers would not recognize a relationship between the child and the non-birthing spouse. ${ }^{51}$ Additionally, one of the couples had a set of twins that were born prematurely and passed away. ${ }^{52}$ Although the State would list the non-birthing spouse on the children's death certificates, it still refused to list her on their birth certificates. ${ }^{53}$ And because the children were deceased, the non-birthing spouse could not even adopt the children as a way to legally establish parentage..$^{54}$

On February 13, 2015, these couples filed a complaint asking the court for a declaratory judgment, arguing that Indiana Code sections 31-9-2-15, 31-9-2-16, and 31-14-7-1 were unconstitutional. ${ }^{55}$ The couple sought injunctive relief to list both the birth mother and her same-sex spouse on their children's birth certificates and to recognize their children as being born in wedlock. ${ }^{56}$ Specifically, they challenged these Parenthood Statutes as violations of the Equal Protection Clause and the Due Process Clause, both facially and as-applied. ${ }^{57}$

Thus far, the plaintiffs have been successful in their constitutional challenges. ${ }^{58}$ The United States District Court for the Southern District of Indiana found that the Parenthood Statutes provide for unequal treatment, based on gender and sexual orientation, because the same presumption of parentage is not afforded to the non-birthing spouse in a same-sex marriage like it is to the nonbirthing spouse in an opposite-sex marriage. ${ }^{59}$ Further, the courts have held that

47. Henderson, 209 F. Supp. 3d at 1063-65.

48. The version that the women filled out did not recognize same-sex couples and only recognized "fathers."

49. Henderson, 209 F. Supp. 3d at 1064-66.

50. Id. at 1065-66.

51. Id.

52. Id. at 1065 .

53. Id. at 1066.

54. Id. at 1065-66.

55. Id. at 1063.

56. Id. at 1066.

57. Id. at 1068, 1072.

58. Id. at 1079-80.

59. Id. at 1074-76. 
the Parenthood Statutes deny the plaintiffs the same parentage rights as oppositesex couples, which has significantly interfered with their ability to exercise the right to be a parent, and therefore the statutes violate the plaintiffs' fundamental rights under the Due Process Clause. ${ }^{60}$

As of now, the non-birthing spouse is recognized on their child's birth certificate as a parent and the State is currently appealing the judgment of the lower court. ${ }^{61}$ On May 22, 2017, the Seventh Circuit heard arguments and has since taken the issue under advisement. ${ }^{62}$ The Supreme Court announced their holding in Pavan shortly after the Seventh Circuit heard the Henderson case. ${ }^{63}$ Although the court has yet to hand down a ruling, it is highly likely that the Seventh Circuit will follow the precedent set in Pavan and allow the non-birthing spouse to be listed on the birth certificate.

2. Indiana Parenthood Statutes.-The current Indiana Parenthood Statutes are very similar to the Arkansas statutes struck down in Pavan. ${ }^{64}$ Indiana Code section 31-9-2-15 provides that for a child to be born "in wedlock," that child must be born to a woman and a man who is presumed to be the father ${ }^{65}$ Indiana Code section 31-9-2-16 stipulates that a child is born "out of wedlock" if a man is not presumed to be the child's father. ${ }^{66}$ In relevant parts, Indiana Code section 31-14-7-1 offers the assumption that a man is a child's biological father if the man and the birthing mother are or have been married to each other, and if the child is born within a 300-day period after the marriage has terminated. ${ }^{67}$ All three statutes specifically rely on the male's status to the child, but all fail to acknowledge that the Obergefell decision allows two women to legally marry in the state of Indiana. ${ }^{68}$ They also fail to consider that just because a woman is married to a male at the time she gave birth, that said male may not in fact have any biological relationship with the child.

3. Indiana's Birth Worksheet.-Although Henderson did not specifically attack the Indiana Live Birth Worksheet, the worksheet is the first step in the process of issuing a birth certificate and is therefore relevant to this discussion. ${ }^{69}$ Each of the eight couples named in Henderson attempted to fill out the worksheet to ensure both spouses were listed on their child's birth certificate. ${ }^{70}$ The Indiana State Department of Health created this worksheet as part of the Indiana Birth Registration System, and the information provided on the worksheet is uploaded

60. Id. at 1077 .

61. Id. at 1079-80.

62. Henderson v. Adams, 2016 WL 7492478 (S.D. Ind. 2016) (No. 115CV00220TWPMJD).

63. Pavan v. Smith, 137 S. Ct. 2075, 2075-76 (2017).

64. See generally ARK. Code ANN. §§ 20-18-401, -406 (2019); IND. CODE $\S \S 31-9-2-15$ to -16, 31-14-7-1 (2019).

65. IND. CODE $§ 31-9-2-15$.

66. Id. $\S 31-9-2-16$.

67. Id. § 31-14-7-1.

68. See generally Obergefell v. Hodges, 135 S. Ct. 2584, 2593 (2015).

69. Henderson v. Adams, 209 F. Supp. 3d 1059, 1066 (S.D. Ind. 2016).

70. Id. at 1064-66. 
to a state database. ${ }^{71}$ The version of the worksheet the Plaintiffs in Henderson completed contained ninety questions, with fifteen specifically concerning the father of the child. ${ }^{72}$ The first question relating to the father asked whether the birthing mother is married to the father of the child. ${ }^{73}$ If the answer to this question was "no," then the worksheet directed the birthing mother to a follow up question asking whether the father has completed a Paternity Affidavit. ${ }^{74}$ If the answer regarding marriage was "yes," then the birthing mother skipped over the question about the Paternity Affidavit and was required to fill out the remaining questions about the father. ${ }^{75}$ At the time, the worksheet did not provide a "samesex marital status" option nor posed any questions about a possible same-sex spouse. ${ }^{76}$ Additionally, nowhere on the worksheet did it specify or define what it meant to be a "father." It It did not state that the father must be the biological father of the child, and it did not indicate that claiming a non-biological father was subject to penalties of perjury. ${ }^{78}$

In April 2017, the Indiana State Department of Health amended the Live Birth Worksheet to include married same-sex couples. ${ }^{79}$ The worksheet still specifically asks questions about the "mother" when referring to the woman who gave birth, but instead of asking if she is married to the "father" of the child, the worksheet simply asks if the woman is married. ${ }^{80}$ She is then provided the ability to check a box indicating "yes, to biological father" or "yes, to same-sex spouse/partner." 81 The remaining questions about the "father" have now been changed to "spouse."

\section{B. Senator Mark Stoops' Alternative Amendments}

Although the State is fighting to keep both spouses in a same-sex marriage from being listed on their child's birth certificate, ${ }^{83}$ not all Hoosiers with decisionmaking capabilities take the same stance. ${ }^{84}$ Senator Mark Stoops has recognized the need for the Indiana General Assembly to amend its Parenthood Statutes to

71. Id. at 1066.

72. Ind. Certificate of Live Birth Worksheet, supra note 14, at 4-6.

73. Id.

74. Id.

75. Id.

76. Id.

77. Henderson v. Adams, 209 F. Supp. 3d 1059, 1074 (S.D. Ind. 2016).

78. Id.

79. Ind. CERTIFICATE of Live BiRTh Worksheet, supra note 14.

80. Id.

81. Id.

82. $I d$.

83. See generally Henderson v. Adams, No. 17-1141 (7th Cir. filed Jan. 23, 2017) (illustrating that appellant, Jerome Adams, continues to file additional authority with the Seventh Circuit in hopes of reversing the lower court).

84. See S. 393, 120th Gen. Assemb., Reg. Sess. (Ind. 2017). 
comply with the United States Constitution. ${ }^{85}$ His amended language affords the female spouse of a birthing mother the same presumption of parentage that husbands of birthing mothers currently enjoy. ${ }^{86}$ On January 10, 2017, just over seven months prior to the Pavan decision, these proposed amendments were read for the first time and referred to the Committee on Civil Law. ${ }^{87}$ However, there has been no additional activity for the bill since that date. ${ }^{88}$ Specific to each statute, and in relevant parts, Senator Stoops has provided the following language be adopted to the Indiana Parenthood Statutes:
$\S 31-9-2-15^{89}$
i) "Child born in wedlock", for purposes of IC 31-19-9, means a child born to a woman and:
(1) a man who is presumed to be the child's father under IC 31-14-7- 1(a)(1) or IC 31-14-7-1(a)(2); or
(2) the woman's female spouse who is presumed to be the child's mother under IC 31-14-7-1(b)(1) or IC 31-14-7-1(b)(2); unless the presumption is rebutted.

\section{§ 31-9-2-16 ${ }^{90}$}

ii) "Child born out of wedlock", for purposes of IC 31-19-3, IC 31-194-4, and IC 31-19-9, means a child who is born to:

(1) a woman; and

(2) a man who is not presumed to be the child's father under IC 31-1471(a)(1) or IC 31-14-7-1(a)(2).

\section{§ 31-14-7-1: ${ }^{91}$}

(b) The female spouse of a child's biological mother is presumed to be a child's mother if:

(1) the:

(A) female spouse and the child's biological mother are or have been married to each other; and

(B) child is born during the marriage or not later than three hundred (300) days after the marriage is terminated by death, annulment, or dissolution; or

85. Id.

86. Id.

87. Id.; Pavan v. Smith, 137 S. Ct. 2075, 2076 (2017) (showing that the holding in Pavan was handed down June 26, 2017).

88. S. 393, 120th Gen. Assemb., Reg. Sess. (Ind. 2017).

89. Id.

90. Id.

91. Id. 
(2) the:

(A) female spouse and the child's biological mother attempted to marry each other by a marriage solemnized in apparent compliance with the law, even though the marriage:

(i) is void under IC 31-11-8-2, IC 31-11-8-3, IC 31-11-8-4, or IC 31-11$8-6$; or

(ii) is voidable under IC 31-11-9; and

(B) child is born during the attempted marriage or not later than three hundred (300) days after the attempted marriage is terminated by death, annulment, or dissolution.

Moving forward, it is very important that the Indiana General Assembly consider Senator Stoops' proposed language. His proposed Parenthood Statutes includes the necessary language that is now required with the U.S. Supreme Court's decision in Pavan. ${ }^{92}$

\section{VARIOUS STATES' APPROACHES TO THE ISSUE}

A handful of states have already adopted legislation allowing both female partners in a same-sex marriage to have the same rights and presumptions of parentage as their opposite-sex counterparts. ${ }^{93}$ Additionally, some states have already amended their Birth Worksheets to allow the collection of information from both spouses in a same-sex marriage, consistent with Obergefell and Pavan. ${ }^{94}$ Although several states provide more gender neutrality than others, both the Indiana General Assembly and the Indiana State Department of Health could benefit immensely from adding the language these states have adopted into their versions of the Parenthood Statutes and the Live Birth Worksheet. Not only would the state be safeguarded against constitutional challenges, but also there are potential economic benefits that could be gained. ${ }^{95}$ Although Indiana should codify its own language, Indiana should look to the Parenthood Statutes and Birth Worksheets of California, ${ }^{96}$ Oregon, ${ }^{97}$ and New York $^{98}$ as examples.

92. See Pavan, 137 S. Ct. at 2075.

93. See Cal. Health \& Safety Code $\S 102425.1$ (West 2019); N.Y. Pub. Health Law $\S$ 4132 (McKinney 2019); OR. REV. STAT. § 432.088 (2018).

94. Cal. Dep't of Pub. Health, Certificate of Live Birth Worksheet, at 1-2 (2017) [hereinafter CAl. Certificate of Live Birth Worksheet]; N.Y.C. DeP'T of Health and Mental Hygiene, Registration of Newborn Birth Certificate, version 203 at 1-4 (2017) [hereinafter N.Y. CertificAte of Live Birth Worksheet]; Or. Health Auth., Oregon Birth RECORD, at 1-2 (2018), available at https://www.oregon.gov/oha/PH/BIRTHDEATH CERTIFICATES/GETVITALRECORDS/Documents/birthor.pdf [https://perma.cc/FA5K-YR2X] [hereinafter OR. CERTIFICATE OF LIVE BIRTH WORKSHEET].

95. See generally Elizabeth Weise, Gay-rights Groups Say Amazon Should Avoid These 9 Cities for Second Headquarters, USA TODAY (Feb. 2, 2018, 3:18 PM), https://www.usatoday. com/story/tech/2018/02/01/amazons-second-headquarters-gay-groups-say-amazon-should-avoidthese-9-cities/1082126001/ [https://perma.cc/3KBG-9SAX].

96. Cal. Health \& Safety Code $§ 102425.1$; Cal. Certificate of Live Birth 


\section{A. California}

The gender-neutral language that California has adopted in its Parenthood Statutes and Live Birth Worksheet can serve as a great model for the Indiana General Assembly and the Indiana State Department of Health in amending the language used in Indiana's current Parenthood Statutes and Live Birth Worksheet. ${ }^{99}$

California Health \& Safety Code section 102425.1 provides that the Live Birth Worksheet shall contain two lines that request "Name of Parent" instead of "Name of Mother" or "Name of Father."100 This gender-neutral language is an excellent example of how the Indiana General Assembly should amend Indiana's Parenthood Statutes to comply with the U.S. Supreme Court's decision in Pavan. ${ }^{101}$ At the very least, it would allow for the non-birthing spouse to be listed as "Parent" on his or her child's birth certificate.

But California's birthing worksheet goes one step further in its neutrality. ${ }^{102}$ Next to the parents' names on the worksheet, the parents are able to choose their relationship with their child from three checkboxes. ${ }^{103}$ These checkboxes allow them to choose between "Mother," "Father," or "Parent." 104 The Indiana State Department of Health should amend the language currently provided on Indiana's Live Birth Worksheet and add the same three checkboxes on Version 31 of the Indiana Live Birth Worksheet.

\section{B. Oregon}

Effective January 1, 2018, Oregon's Mandatory Registration of Births statute was amended to specify "birth mother" instead of "mother." 105 Additionally, it provides same-sex couples the same presumption as opposite-sex couples in that the non-birthing spouse will be presumed to be the parent of the child unless determined otherwise. ${ }^{106}$ If Indiana were to adopt similar language into their Parenthood Statutes, it would no longer violate the Equal Protection Clause or the Due Process Clause.

WORKSHEET, supra note 94

97. Or. Rev. Stat. $\S \S 432.088,109.065$; Or. Certificate of Live Birth Worksheet, supra note 94.

98. N.Y. Pub. Health LaW § 4132; N.Y. Certificate of Live BiRth Worksheet, supra note 94 .

99. Cal. Health \& Safety Code $§$ 102425.1; Cal. Certificate of Live Birth WORKSHEET, supra note 94.

100. Cal. Health \& Safety Code $§ 102425.1$.

101. See Pavan v. Smith, 137 S. Ct. 2075 (2017).

102. Cal. Certificate of Live Birth Worksheet, supra note 94, at 1.

103. Id.

104. Id.

105. OR. REV. StAT. § 432.088 (2018).

106. Id. 
The language on Oregon's Birth Record Parent Worksheet is similar to the language provided on Version 30 of Indiana's Live Birth Worksheet. The worksheet presented to Oregon couples provides a section for "Father/Second Parent" and the worksheet provided to Indiana couples asks about the "Spouse" of the birthing mother. ${ }^{107}$ Ideally, moving forward, both states will amend the language of the documents to be even more gender-neutral without a court demanding it to do so. But for the time being, the Indiana State Department of Health should at least recognize that the language used on Version 30 of the Indiana Live Birth Worksheet is heading in the right direction.

\section{New York}

The most current version of New York's Live Birth Worksheet specifies "Mother/Parent (Woman Giving Birth)" and allows for that person to choose between "male" or "female" when choosing their sex. ${ }^{108}$ Additionally, the worksheet refers to the person who did not give birth as "Father/Parent" and again provides that person with the applicable checkboxes for both genders. ${ }^{109}$ The Indiana General Assembly and the Indiana State Department of Health would benefit by following New York and recognizing that the birthing parent and the non-birthing parent can identify as either sex. In making said recognition, at the very least, it would reflect that it is no longer safe to assume that every child is born to a "mother" as it could have been born to a "parent."

Currently, New York state Senator Brad Hoylman has proposed an amendment to allow the second parent to be designated as either "father," "mother," or "parent." 110 The amendment is specific to the second parent, and does not provide the birthing parent the same relationship choices. But if Senator Hoylman's proposed amendment is enacted, the Indiana General Assembly piggy-back on other states that are evolving their ideals about parentage and showing more gender neutrality. ${ }^{111}$

\section{RIGHTS OF THE TRANSGENDER COMMUNITY}

With transgender rights being on the frontier of social change, it is imperative that the Indiana Parenthood Statutes and Indiana Live Birth Worksheet be amended to include gender-neutral language. ${ }^{112}$ Although transgender rights are not explicitly addressed in Pavan or Henderson, there is currently a considerable

107. Ind. Certificate of Live Birth Worksheet, supra note 14, at 4; Or. CertificAte of LIVE BIRTH WORKSHEET, supra note 94, at 2.

108. N.Y. Certificate of Live Birth Worksheet, supra note 94.

109. Id.

110. S. S00075, 2017-2018 Assemb., Reg. Sess. (N.Y. 2017).

111. See generallyid.

112. See generally Know Your Rights: Transgender People and The Law, ACLU, https://www. aclu.org/know-your-rights/transgender-people-and-law [https://perma.cc/P7EE-89SZ] (last visited Feb. 7, 2018). 
push to increase the rights for transgendered individuals nationwide. ${ }^{113}$ That movement is comparable to many civil rights movements seen throughout U.S. history. ${ }^{114}$ If the Indiana General Assembly and the Indiana State Department of Health were to include gender-neutral language in their respective statutes and documents, Indiana could avoid future litigation and, in some ways, could be ahead of the human rights curve.

\section{A. Defining Transgender}

The term "transgender" is an encompassing term for a person who does not identify with their biological sex. ${ }^{115}$ For example, a person could be born with female genitalia but internally feel that both their physical and mental ideologies align better with characteristics societally typical of the male gender. ${ }^{116}$ Advocates of the transgender community hold that the term "gender" is much deeper than simply being a male or a female. Instead, they use the term as an umbrella for gender identity, gender expression, sex assigned at birth, and physical attractions. ${ }^{117}$ Gender identity refers to what sex an individual considers himself or herself to be. ${ }^{118}$ Gender expression signifies the way a person physically manifests their gender through clothing, hairstyle, etc. ${ }^{119}$ Sex assigned at birth refers to the gender an individual is assigned based solely on their genitalia. ${ }^{120}$ Physical attraction indicates different factors, such as a combination of the components above, that appeal to a particular person. ${ }^{121}$

That the term gender has more than one meaning is something that the Indiana General Assembly and Indiana State Department of Health need to recognize. ${ }^{122}$ In doing so, they should acknowledge that a person's gender identity and sex assigned at birth could differ and in turn, adopt gender-neutral language for Indiana's Parenthood Statutes and Live Birth Worksheet. ${ }^{123}$

\section{B. Transgender Rights as an Extension of Civil Rights}

Minorities fighting for their fundamental rights are by no means a recent

113. See generally Flavia Krause-Jackson, Transgender Rights, BloOMBERG (Oct. 30, 2017, 3:17 PM), https://www.bloomberg.com/quicktake/transgender-rights [http://perma.cc/ZNR8-P26R].

114. Id.

115. Transgender People, Gender Identity and Gender Expression, Am. Psychol. Ass'N, http://www.apa.org/topics/lgbt/transgender.aspx [https://perma.cc/BVG6-U3E2] (last visited Feb. 7, 2018).

116. Gender Unicorn, Trans Student Educ. Resources, http://www.transstudent.org/ gender [https://perma.cc/VFR6-2QGR] (last visited Feb. 7, 2018).

117. Id.

118. Id.

119. Id.

120. Id.

121. Id.

122. See generally Gender Unicorn, supra note 116.

123. See generallyid. 
development in the United States. ${ }^{124}$ The first major push for equality can be seen by the Civil Rights Movement in 1955, which started after a 42-year old African American woman named Rosa Parks was arrested for refusing to give up her seat at the front of the bus to a white man. ${ }^{125}$ At the core of the Civil Rights Movement were the notions that race is an immutable characteristic and that a person should not be discriminated against for the way they are biological programmed. ${ }^{126}$ It took many years, legal battles, and various legislative acts, but finally in 1968, President Lyndon B. Johnson signed the Fair Housing Act into law. ${ }^{127}$ This stands as the final great achievement of the civil rights era. ${ }^{128}$

The Gay Rights Movement began just a few years after the Civil Rights Movement ended. ${ }^{129}$ Many people attribute the beginning of the Gay Rights Movement to the Stonewall Riots in New York. ${ }^{130}$ Supporters of the movement adopted the same argument that had prevailed in the Civil Rights Movement, arguing that gay and lesbian individuals should not be discriminated against because sexual orientation is immutable. ${ }^{131}$

Although the Gay Rights Movement is by no means over, the movement has provided members of the LGBT community with many civil right victories. ${ }^{132}$ In recent years, the Obergefell decision is arguably the biggest success the group has seen ${ }^{133}$ In his majority opinion, Justice Kennedy found that the petitioners sought marriage for themselves "because of their respect-and need-for its privileges and responsibilities. And their immutable nature dictates that same-sex marriage is their only real path to this profound commitment." 134 By using the term "immutable" when referencing the petitioner's sexual orientation, he struck down the argument that being a homosexual is a choice. ${ }^{135}$ Instead, Justice Kennedy held that just as one is born into a certain race, one is also born with a

124. See generally Civil Rights Movement, HISTORY, https://www.history.com/topics/blackhistory/civil-rights-movement [https://perma.cc/U7UG-HG6J] (last visited on March 15, 2018).

125. Id. (giving Rosa Parks the title of "mother of modern day civil rights movement.").

126. Vittoria L. Buzzelli, Transforming Transgender Rights in Schools: Protection from Discrimination Under Title IX and the Equal Protection Clause, 121 Penn St. L. Rev. 187, 199 (2016).

127. Fair Housing Act, HISTORY, https://www.history.com/topics/black-history/fair-housingact [https://perma.cc/3FKE-BFGW] (last visited March 15, 2018).

128. Id. (" $[\mathrm{t}]$ he Fair Housing Act of 1968 prohibited discrimination concerning the sale, rental and financing of housing based on race, religion, national origin or sex").

129. Stonewall Riots, HistORY, https://www.history.com/topics/the-stonewall-riots [https:// perma.cc/C7LB-5PVJ] (last visited March 15, 2018).

130. Id. (noting that the Stonewall Riot itself did not start the Gay Rights Movement but that it was a catalyst for LGBT political activism).

131. Buzzelli, supra note 126, at 199.

132. See generally id. at 199-201.

133. See generallyid.

134. Obergefell v. Hodges, 135 S. Ct. 2584, 2594 (2015).

135. See generally id. 
predisposed sexual orientation. ${ }^{136}$ Although the LGBT community is still fighting to gain protected class status for homosexual individuals, they now enjoy much greater equality than those who rallied together immediately after the Stonewall Riots. ${ }^{137}$

In many aspects, the Transgender Rights Movement can be thought of as an extension of previous civil rights movements such as gay rights, women's rights, and the rights of racial minorities. ${ }^{138}$ Just as sexual orientation is an immutable characteristic, so is someone's gender identity. ${ }^{139}$

In recent years the LGBT community has publicly attacked school policies that discriminate against transgender students in regard to bathroom usage and Title IX. ${ }^{140}$ In October 2016, right before the presidential election, the U.S. Supreme Court agreed to hear its first case involving transgender rights. ${ }^{141}$ But five months later, in March 2017, the Court provided a one-sentence order vacating a decision in favor of a transgender student and decided not to hear the case. $^{142}$

Although the Court's decision to not hear the case was a setback to the transgender community, that it initially agreed to hear the case left many people hopeful the Court will begin hearing cases involving transgender rights one day soon. ${ }^{143}$ And once the U.S. Supreme Court finally takes its first transgender rights case, the reasoning behind the Obergefell decision could serve to expand gender identity to the list of protected immutable characteristics. ${ }^{144}$

\section{Current Indiana Transgender Laws}

The Indiana Court of Appeals has ruled that the sole requirement for a person to legally change their gender in Indiana is for it to be done "in good faith and not for a fraudulent or unlawful purpose." 145 To date, the Indiana General Assembly has fallen silent on the topic. ${ }^{146}$ Therefore, providing gender-neutral language in

136. See generally id.

137. See Kate Brumback, Court: Discrimination Against Gay Workers Not Prohibited, AP News (Mar. 13, 2017), https://apnews.com/7cf28f27f2af4c7babb78d4043baa958 [https://perma. cc/ER9T-3RFY].

138. Jeannie Suk Gersen, A New Phase of Chaos on Transgender Rights, NEw YORKER (Mar. 13, 2017), https://www.newyorker.com/news/news-desk/a-new-phase-of-chaos-on-transgenderrights [https://perma.cc/D6DP-LPD5].

139. See Buzzelli, supra note 126 , at 200.

140. Id. at 201.

141. Adam Liptak, Supreme Court Won't Hear Major Gender Case on Transgender Rights, N.Y. Times (Mar. 6, 2017), https://www.nytimes.com/2017/03/06/us/politics/supreme-courttransgender-rights-case.html [https://perma.cc/54H6-6GXB].

142. $I d$.

143. See id.

144. See generally Obergefell v. Hodges, 135 S. Ct. 2584 (2015).

145. See In re A.L., 81 N.E.3d 283, 289 (Ind. Ct. App. 2017).

146. See generally id. 
the Parenthood Statutes and Live Birth Worksheet should not present any conflicts to either the Indiana General Assembly or the Indiana State Department of Health. ${ }^{147}$ And although it is likely an unintended consequence, the Indiana General Assembly's inaction has opened the door for a Hoosier to change from a female to a male but continue to have the ability to bear children. ${ }^{148}$ Thus, it is no longer out of the realm of possibilities for a man to give birth in the state. ${ }^{149}$ Additionally, there is no legislation that would keep a person who has given birth as a female from having gender reassignment surgery post birth. ${ }^{150}$ These simple facts, coupled with the Transgender Rights Movement, make it imperative that the Indiana General Assembly and Indiana State Department of Health recognize the writing on the wall and the potential litigation to which they have exposed themselves. In doing so, they should amend their respective statutes and documents to reflect the gender-neutrality that will provide all Hoosiers parenting equality and allow Indiana to avoid defending-with tax payer dollars - constitutional challenges.

\section{A PROPOSED APPROACH FOR INDIANA}

Although the language that has been proposed by Senator Stoops and the new language provided on Version 30 of Indiana's Live Birth Worksheet are steps in the right direction, the language in both still unnecessarily emphasizes gender roles. Even if the Indiana General Assembly was to adopt Senator Stoops' amended language, the transgender community would continue to lack the necessary parentage rights to enable them to be represented on their child's birth certificate with a true depiction of the relationship they will have with their child.

\section{A. Proposed Language for Indiana Parenthood Statutes}

The Indiana General Assembly should adopt the following gender-neutral language to keep its Parenthood Statutes compliant with the United States Constitution and adhere to societal and technological progressions:

\section{§ 31-9-2-15}

i) “Child born in wedlock", for purposes of IC 31-19-9, means a child born to an individual and:

(1) an individual who is presumed to be the child's parent under IC 3114-7-1(a)(1) or IC 31-14-7-1(a)(2).

\section{$\S 31-9-2-16$}

ii) “Child born out of wedlock", for purposes of IC 31-19-3, IC 31-19-

\footnotetext{
147. Id.

148. See id.

149. See id.

150. See id.
} 
4-4, and IC 31-19-9, means a child who is born to:

(1) an individual; and

(2) an individual who is not presumed to be the child's parent under IC 31-14-71(a)(1) or IC 31-14-7-1(a)(2).

\section{$\S 31-14-7-1$ in relevant parts:}

iii) An individual is presumed to be a child's parent if:

(1) the:

(A) individual and the child's birthing parent are or have been married to each other; and

(B) child is born during the marriage or not later than three hundred (300) days after the marriage is terminated by death, annulment, or dissolution;

(2) the:

(A) individual and the child's birthing parent attempted to marry each other by a marriage solemnized in apparent compliance with the law, even though the marriage:

(i) is void under IC 31-11-8-2, IC 31-11-8-3, IC 31-11-8-4, or IC 31-11$8-6$; or

(ii) is voidable under IC 31-11-9; and

(B) child is born during the attempted marriage or not later than three hundred (300) days after the attempted marriage is terminated by death, annulment, or dissolution; or

(3) an individual undergoes a genetic test that indicates with at least a ninety-nine percent $(99 \%)$ probability that the individual is the child's biological parent.

Critics may claim that gender roles are important to the statutes and the worksheet because birth certificates are used as recording devices for biological parentage and genetic conditions, ${ }^{151}$ but this argument is invalid for several reasons. First, husband of a woman who gave birth is automatically presumed to be the biological father of that child. By making this assumption, and not requiring the husband to prove he is biologically the father, Indiana lacks assurance whether the records they are keeping actually link a child to their biological father and his genetic conditions. Like same-sex couples, many opposite-sex couples rely on artificial insemination. ${ }^{152}$ In the opposite-sex situation, the husband has no more biological relation to the child than the nonbirthing spouse in a same-sex marriage. Therefore, such biological integrity arguments fall short.

Second, through the Pavan decision, both female spouses in a same-sex

151. Smith v. Pavan, 505 S.W.3d 169, 178-80 (2016).

152. See generally Pavan v. Smith, 137 S. Ct. 2075, 2077 (2017) (showing that Arkansas has a statute that specifically deals with artificial insemination with heterosexual couples which demonstrates that it is not uncommon for an opposite sex couple to use such a technique). 
couple must be represented on their child's birth certificate. ${ }^{153}$ When such an instance occurs, only one of the women listed as a parent on the birth certificate actually has any biological ties to the child. This means that when a married female same-sex couple has a child, that child's birth certificate only reflects fifty percent of their genetic make-up. Therefore, Indiana's data regarding biological parentage will no longer be accurate, even if the Indiana General Assembly and Indiana State Department of Health kept gender roles in the Parenthood Statutes and Live Birth Worksheet.

Third, as social acceptance and technological developments reshape the ideas of parentage, the meaning behind a birth certificate must adapt to reflect new ideals. In today's world, the woman giving birth may not actually have any biological relationship to that child. ${ }^{154}$ It is now possible for a female to have another woman's egg fertilized and implanted into her uterus via in vitro fertilization. ${ }^{155}$ This was the case for one of the couples, Jackie and Lisa PhillipsStackman, who brought suit in Henderson. ${ }^{156}$ During the in vitro process, the couple had Jackie's egg fertilized from a third-party sperm donor and then implanted in Lisa. ${ }^{157}$ Although Jackie is technically the biological parent, the Marion County Health Department regarded Lisa as the child's sole mother because she is the one who gave birth. ${ }^{158}$ It refused to list Jackie as a parent on the child's birth certificate absent a court order. ${ }^{159}$

Additionally, because the Indiana General Assembly has yet to adopt any statutory language regarding how one changes one's gender-such as requiring one to become infertile through sterilization - a person may give birth as one gender and later identify with the other. Consequently, it is no longer safe for the Indiana General Assembly and Indiana State Department of Health to assume that the information provided on the worksheet for the birthing mother will accurately meet any goal of biological parentage and genetic conditions record keeping.

It is also likely that many people will push back on the proposed legislation and ask why Indiana - a historically conservative state - should model its statutes on liberal states like California, Oregon, and New York. After all, neither the Obergefell nor the Pavan decisions mention that a state must provide their citizens the opportunity to be listed however they choose on a birth certificate. Moreover, neither decision mentions what rights a state must provide their transgendered citizens. All Indiana must do to comply with the precedent handed down in Obergefell and Pavan is allow both same-sex female spouses to be listed on their child's birth certificate.

Although these arguments may be true, there are several reasons why extending the language of its Parenthood Statutes to reach beyond the minimum

153. Id. at 2078-79.

154. Henderson v. Adams, 209 F. Supp. 3d 1059, 1066 (S.D. Ind. 2016).

155. Id.

156. Id.

157. Id.

158. Id.

159. Id. 
and mimic the language of the liberal states suggested will benefit Indiana. For instance, adopting gender-neutral language will not only extend parentage rights to an oppressed group of people, it will also save the tax payers time and money in not having to litigate the issue at a future date. Additionally, the gender-neutral language could have a major economic impact on the state.

While Indiana may not currently be in the national spotlight for its Parenthood Statutes, many Americans have not forgotten the Religious Freedom Restoration Act (RFRA) signed into law in 2015. ${ }^{160}$ To many Americans, RFRA was nothing more than a way to discriminate against same sex couples in a time when gay marriage was on the brink of being legal countrywide. ${ }^{161}$ As a direct result of RFRA, Indiana saw a fierce reaction of economic boycotts and negative publicity. ${ }^{162}$ Even with the amended language that was added after the backlash, Indiana is still known to be an anti-LGBT state, and that reputation may discourage some companies from starting and/or expanding their businesses in Indiana. ${ }^{163}$

Though the adoption of the proposed Indiana Parenthood Statutes alone will not completely end the anti-LGBT stigma that plagues Indiana, it is a major step in the right direction. The proposed legislation goes further than just providing same-sex couples the ability to be listed on their child's birth certificate; it includes the rights of transgendered individuals. Indiana could make a strong case - perhaps to a company considering bringing its business to Indiana - that it is not a state that discriminates against the LGBT community. Instead Indiana could assure companies that all of their employees will enjoy the same parentage rights as any other Hoosier.

In the event the Indiana General Assembly finds the proposed language to be too liberal and/or progressive, at the very least it should amend the Indiana Parenthood Statutes to reflect those of Oregon's. In doing so, it would comply with both the Equal Protection and the Due Process Clause. Some critics are likely to argue that Oregon is too liberal of a state for Indiana to model legislation

160. Andrew Bender, Indiana's Religious Freedom Act Cost Indianapolis \$60 Million In Lost Revenue, FORBES (Jan. 31, 2016, 2:28 PM), https:/www.forbes.com/sites/andrewbender/2016/ 01/31/indianas-religious-freedom-act-cost-indianapolis-60-million-in-lost-revenue/\#336968612e2a [https://perma.cc/29CM-2R5N].

161. Id.

162. Id.

163. Weise, supra note 95. Indianapolis is currently on the short list of locations for Amazon's second headquarters, "H2Q." If Amazon were to pick Indianapolis for H2Q it could have a \$6.5 billion impact on Indiana wages and could generate up to 35,000 jobs via indirect job creation. A company of this magnitude coming to Indiana would be felt state-wide. However, of the 20 finalists that made the list, Indianapolis is among 8 other locations in which are believed to have no anti-gay discrimination laws. As a result, gay right advocates plan on applying pressure to Amazon through their "No Gay? No Way!" campaign in hopes that they will drop Indianapolis from their list of potential cities. Billboards are also popping up in Seattle, the city where Amazon is headquartered, that say: "Hey, Alexa? Why would Amazon even consider H2Q in a state that discriminates against LGBT people?" 
after, but not only does the language of its statute solely address the issue of same-sex couples but the Oregon State Constitution is practically a carbon copy of Indiana's. ${ }^{164}$ In turn, this means that both states are essentially relying on the same play book in the way their courts decide cases and legislators draft laws.

\section{B. Proposed Language for Indiana Live Birth Worksheet Version 31}

The Indiana State Health Department should amend the Indiana Live Birth Worksheet to mirror California's Birth Worksheet. ${ }^{165}$ Indiana's Live Birth Worksheet needs to ask whether the birthing parent is married. If the answer to this question is "no," then the birth parent should be directed to answer whether a Parentage Affidavit, and not a "Paternity Affidavit," has been completed. By changing the wording from "Paternity" to "Parentage" the worksheet is focused less on gender and focused more on accurately recording the child's parents. Additionally, it will allow for non-married same-sex couple to have the same rights as a non-married opposite-sex couple. Although no case before the U.S. Supreme Court has set the precedent of listing both partners in a non-married same-sex relationship on a birth certificate, this is likely a natural next step that will ensue from Pavan. Adopting the proposed language would allow Indiana to get ahead of this future litigation.

If the answer to the marriage question is "yes," then the birthing parent should be directed to questions about the "Second Parent" rather than "Father". When presented with the legal name of the Second Parent and that parent's relationship to the child, there should be the same three checkboxes adopted by California that allow the Second Parent to choose whether they would like to be identified as that child's "Mother," "Father," or "Parent." Not only would this resolve the problem that same-sex couples face when filling out the Indiana's Live Birth Worksheet, but this would also serve as a way to incorporate the concerns of transgendered persons. These checkboxes permit a person to choose their relationship to the child based on whatever gender they personally identify. No longer would the State of Indiana define parents' relationships to their children for them.

Additionally, the questions about the person giving birth should be changed to say, "Birthing Parent" and the birthing parent should also be presented with the same three checkboxes of "Mother," "Father," or "Parent" when filling out the worksheet. It should be the birthing parents' choice as to the relationship they will have with their child and how they will be listed on the birth certificate. Of all the autonomous choices a parent makes in the upbringing of their child, the relationship they choose to have with said child is arguably the most important. This relationship should not be decided for them. If the person who gives birth to the child makes the choice to play a father-like role in that child's life, then it is illogical to not honor that relationship.

164. Suzanne L. Abram, Problems of Contemporaneous Construction in State Constitutional Interpretation, 38 BRANDEIS L.J. 613, 613-14 (2000).

165. Cal. Certificate of Live Birth Worksheet, supra note 94. 
Some will argue that allowing the birthing parent to be listed as "father" is an oxymoron because genetically a man is unable to give birth. But the governing rule of law simply requires that the person change their gender "in good faith and not for fraudulent or unlawful purposes." ${ }^{" 166}$ Consequently, it is possible that a Hoosier who identifies as a male could still anatomically have female reproductive parts and could give birth. From this situation could stem at least two possible scenarios.

The first scenario is that the person could have already legally changed their gender from female to male and is legally a man. In this instance, it would also be an oxymoron to identify a legal male as the "mother" of the child. In fact, this exact scenario has already transpired in the United States. ${ }^{167}$ Thomas Beatie was the first American man to become pregnant. ${ }^{168}$ Thomas was born with female reproductive parts in 1974 and had gender reassignment surgery in 2012. ${ }^{169}$ However, because Arizona did not require sterilization in order to change one's gender, Thomas opted to remain fertile. ${ }^{170}$

Thomas later met and married a woman, Nancy Gillespies. ${ }^{171}$ Since Nancy was unable to have children, the couple agreed that Thomas would be the one to get pregnant and carry their children and Nancy would adopt them. ${ }^{172}$ In all, Thomas carried and delivered all three of the couple's children. ${ }^{173}$ Thomas and Nancy are by no means the only American couples that have found themselves in this situation.

In the second scenario, a person could give birth as a legal female but shortly after change their gender marker to male. In fact, in 2017, Kaci Sullivan, a transgender man from the Wisconsin, became the first person to give birth as both a female and a male. ${ }^{174}$ Although he identified as a female when he gave birth the first time, he has since undergone gender reassignment surgery and is now a father, and not a mother. ${ }^{175}$ Thus, this shows not only the potential but also a realistic example of how a person can change their gender after having a child.

166. See In re A.L., 81 N.E.3d 283, 289 (Ind. Ct. App. 2017).

167. Guy Trebay, He's Pregnant. You're Speechless., N.Y. Times (June 22, 2008), http://www.nytimes.com/2008/06/22/fashion/22pregnant.html [https://perma.cc/39Y3-UHQT].

168. Id.

169. Id.

170. Id.

171. Michael Kiefer, 'Pregnant Man's' Divorce Case Leaves Judge in Doubt, USA TODAY (Dec. 12, 2012, 8:22 PM), https://www.usatoday.com/story/news/2012/12/12/pregnant-mansdivorce-case/1765359/ [https://perma.cc/K684-NZZT].

172. $I d$.

173. Id.

174. Julie Mazziotta, Transgender Man Gives Birth to Baby 5 Years After Having a Child as a Woman, People (Dec.15, 2017, 02:40 PM), http:/People.Com/Bodies/Transgender-Man-GivesBirth-Five-Years-After-Having-Child-As-Woman/ [https://perma.cc/83BJ-JXEN] (Kaci had previously given birth to his first child when he still identified as a woman and before he had undergone a gender reassignment).

175. Id. 
Therefore, Indiana should recognize that with social progression and the lack of legislation on behalf of the General Assembly, a person could in fact be a legal male at the time of giving birth or could change their gender afterward.

Even if the Seventh Circuit Court of Appeals does not follow the precedent set by the U.S. Supreme Court, it is imperative that the Indiana General Assembly amends their Parenthood Statutes to comply with the recent decision in Pavan. In doing so, the General Assembly and Indiana State Department of Health should adopt the proposed language, which protects all Hoosiers regardless of their gender identity or physical attraction.

\section{CONCLUSION}

The Indiana General Assembly can no longer deny that birth certificates play a much larger role in society than a simple record of biological parentage and genetics. Being listed on a birth certificate provides the parents of a child a great deal of rights and abilities that are afforded solely to them. In two separate, but extremely significant cases, the U.S. Supreme Court has recognized the importance of affording both spouses in a same-sex marriage the ability to be listed on their child's birth certificate. ${ }^{176}$ In fact, the U.S. Supreme Court has ruled it unconstitutional to deny married same-sex couples this fundamental right. ${ }^{177} \mathrm{It}$ is now time that the Indiana General Assembly also recognizes that denying same-sex couples the ability to be listed on their child's birth certificate is unconstitutional and, subsequently, amend Indiana's Parenthood Statutes to reflect this new precedent.

Moreover, it is imperative that both the Indiana General Assembly and Indiana State Department of Health examine the future litigation that is likely to ensue from both non-married same-sex couples as well as from the Transgendered Rights Movement. In doing so, they need to get ahead of these future lawsuits by using precise, gender-neutral language, as suggested in this Note, which provides both non-married same-sex couples and transgendered persons the ability to be listed on their child's birth certificate.

176. Pavan v. Smith, 137 S. Ct. 2075 (2017); Obergefell v. Hodges, 135 S. Ct. 2584 (2015).

177. See generally Pavan, 137 S. Ct. 2075; Obergefell, 135 S. Ct. 2584. 


\author{
APPENDIX $\mathbf{A}^{178}$ \\ PROPOSED AMENDED CERTIFICATE OF LIVE BIRTH WORKSHEET
}

12. BIRTHING PARENT: What is your current legal name? ${ }^{179}$

$\overline{\text { First }} \overline{\text { Middle }} \overline{\text { Last }} \overline{\text { Suffix (Jr. III, etc. }}$
RELATIONSHIP TO CHILD: $\square$ MOTHER $\square$ FATHER $\square$ PARENT

24. BIRTHING PARENT: What is your race? (Please check all that apply).

$\square$ White $\square$ Black or African American

$\square$ American Indian or Alaska Native (name of enrolled or principal tribe(s))

$\square$ Asian Indian $\square$ Chinese $\square$ Filipino
$\square$ Japanese $\square$ Korean $\square$ Vietnamese $\square$ Other Asian (specify)
$\square$ Native Hawaiian $\square$ Guamanian or Chamorro $\square$ Samoan $\square$ Other Pacific Islander
(specify)_ Other (specify)

BIRTHING PARENT: Additional Information to Be Filled in IF a PARENTAGE AFFIDAVIT IS TO BE FILED for this birth. If Not Filing a Parentage Affidavit, skip to question 30.

\title{
37. BIRTHING PARENT Marital Status: ARE YOU MARRIED?
}

Yes [Please go to question 39]

$\square$ No [Please go to question 38]

38. If not married to Biological Parent, has a Parentage Affidavit been completed for this child?

- $\square$ Yes, a parentage affidavit has been completed If Yes, Date Affidavit was signed:

- $\bar{\square}$ No, a parentage affidavit has not been completed If No, please go to question 53

178. Changes proposed in this Note are italicized.

179. "Mother" needs to be changed to "Birthing Parent" a total of forty-one times on the worksheet. 
39. NON-BIRTHING PARENT: What is your current legal name? ${ }^{180}$

$\overline{\text { First }}$
RELATIONSHIP TO CHILD: $\square$ MOTHER $\square$ FATHER $\square$ PARENT

BIOLOGICAL PARENT Additional Information to Be Filled IF a PARENTAGE AFFIDAVIT IS TO BE FILED for this birth. [If Not Filing Parentage Affidavit, skip to question 53]

49. What is the name of your Employer (Company name)? Optional

51. What is the name of your Medical Insurance Company? Optional

52. BIOLOGICAL PARENT: What is your Medical Insurance Policy Number? (Optional)

180. "Spouse" needs to be changed to "Non-Birthing Parent" a total of twelve times on the worksheet. 